\title{
Comment
}

\section{Must Every Appeal Run the Gamut?-The Civil Appeals Management Plan}

\author{
Irving R. Kaufman†
}

The art of adjudication is rarely associated with the pursuit of compromise, and judges themselves often approach settlement conferences with timidity and trepidation. Perhaps we sense in the concept of settlement a certain lawlessness-by which I do not mean disrespect for the law, but merely divorce from it-for settlements are neither dictated nor even necessarily driven by statutes and stare decisis, the formality and authority that are the well-worn, comfortable clothes of the judicial profession.

Judges, however, are the first to admit that experience is the best teacher. For years I observed and participated in the operation of pre-trial conferences in our district courts, ${ }^{1}$ and my experiences convinced me that

+ Judge and former Chief Judge, United States Court of Appeals for the Second Circuit. I am grateful to Robert Lipscher, former Second Circuit Executive, presently Director of the Administrative Office of the Courts of New Jersey, and Professor Nathaniel Fensterstock, the first Staff Counsel of CAMP, who helped launch the CAMP program.

1. Pre-trial conferences in the federal district court are authorized by Rule 16 of the Federal Rules of Civil Procedure, which provides in relevant part:

(a) Pre-trial Conferences; Objectives. In any action, the court may in its discretion direct the attorneys for the parties and any unrepresented parties to appear before it for a conference or conferences before trial for such purposes as

(1) expediting the disposition of the action;

(2) establishing early and continuing control so that the case will not be protracted because of lack of management;

(3) discouraging wasteful pretrial activities;

(4) improving the quality of the trial through more thorough preparation, and;

(5) facilitating the settlement of the case.

FED. R. Civ. P. 16.

The 1983 amendment of Rule 16 was intended to encourage active judicial oversight of a case early in the litigation, reflecting the drafters' belief that settlement before trial could be achieved sooner and with less cost to the parties. See FED. R. Civ. P. 16 advisory committec note (1983). See generally Kaufman, The Federal Rules: The Human Equation Through Pretrial, 44 A.B.A. J. 1170 (1958) 
introduction of a similar program on the appellate level would produce equally fruitful results. Twelve years ago, during my first year as Chief Judge of the Second Circuit, I designed a program to inject courtsponsored mediation in settlement proceedings into appellate litigation. Instituted in 1974, the Givil Appeals Management Plan (CAMP) ${ }^{2}$ had several major aims: (1) to encourage the resolution of appeals without participation by judges, thus preserving their scarcest and most precious asset, time; (2) to expedite the consideration of appeals that will be briefed and argued, (3) to have Staff Counsel help the parties clarify the issues on appeal; and (4) to dispose of minor procedural motions without expenditure of judicial resources. CAMP was unique among appellate case management programs because it undertook to wrestle with overcrowded dockets in a manner that was not purely administrative.

Today, GAMP stands as a model of judicial reform in an era when courts are bursting at the seams. ${ }^{3}$ In its first decade CAMP has overcome skepticism, ${ }^{4}$ spurred imitation, ${ }^{5}$ relieved court dockets, ${ }^{6}$ and spawned stud-

(district court pretrial procedures resulted in substantial reductions in trial waiting period).

2. CAMP rules have the force and effect of local court rules. The CAMP Rules are reprinted in 28 U.S.C.A., United States Courts of Appeals Rules, Second Circuit, at 487-93 (West 1980) (hereinafter cited as CAMP Rules].

CAMP has its roots in Federal Rule of Appellate Procedure 33, which provides:

The court may direct the attorneys for the parties to appear before the court or a judge thereof for a prehearing conference to consider the simplification of the issues and such other matters as may aid in the disposition of the proceeding by the court. The court or judge shall make an order which recites the action taken at the conference and the agreements made by the parties as to any of the matters considered and which limits the issues to those not disposed of by admissions or agreements of counsel, and such order when entered controls the subsequent course of the proceeding, unless modified to prevent manifest injustice.

FED. R. APP. P. 33.

3. The proliferation of lawsuits and appeals is a well-documented phenomenon affecting almost every part of the legal community. See, e.g., R. Posner, The Federal Courts 59-93 (1985).

4. Any plan proposing a radical departure from traditional legal practices attracts its share of disbelievers and detractors, and CAMP was no exception. Lord MacMillan put it succinctly: "Reform of procedure is always a ticklish business, for we grow accustomed to the paths we have long trodden, however tortuous . . . . But the task must be undertaken from time to time if the vehicle of law is to keep pace with the changing requirements of the age." LORD MACMILLAN, LAW AND OTHER Things 34-35 (1937).

Although the Plan to Expedite the Processing of Criminal Appeals in the Second Circuit had substantially improved the disposition time in criminal appeals, see R. LIPSCHER, Average TIME Study: Cases Processed Since Implementation of the Plan to Systematize the Early Stages of the Criminal Appeal Process 4 (1974), many judges believed a similar program for civil appeals, aimed at settlement as well as expedition, would be a futile endeavor. The CAMP proposal was approved by the Second Circuit Judicial Council only after I presided over the conference of five randomly selected cases and succeeded in obtaining settlements in all five cases merely by offering the adversaries a forum in which to discuss their differences. Even with the approval of the Judicial Council, however, CAMP would not have been economically feasible without the intervention of Chief Justice Warren Burger, who secured the first grant from the Federal Judicial Center to finance the CAMP project because he believed deeply in judicial administrative experimentation.

5. See infra text accompanying notes 34-42.

6. Statistics governing appeals filed in the Second Circuit indicate no abatement of society's evergrowing appetite for litigation. The figures are sobering. In fiscal 1974, there were 1,802 filings in the Second Circuit, of which 1,288 were civil cases. R. LIPSCHER, REPORT OF THE CIRCUIT EXECUTIVE, 
ies. $^{7}$ In a nation that has come to view its court system as a forum of first, not last, resort, CAMP offers an alternative to protracted, full-blown appellate proceedings. With its progeny, it has propelled appellate courts to the vanguard of the movement toward non-adjudicative paths of dispute resolution.

\section{Overview of THE CAMP Procedures}

The centerpiece of CAMP is the Staff Counsel, who conducts the preargument conference and is responsible for administration of the program. ${ }^{\mathbf{8}}$ With few exceptions, all civil cases docketed in the Second Circuit are referred to CAMP. ${ }^{9}$ The appellant must submit a "Pre-Argument Statement" within ten days of docketing an appeal. ${ }^{10}$ Shortly thereafter, Staff Counsel issues a scheduling order, designating the week of argument, the proposed date for a CAMP conference, and deadlines for the

Untren States Courts fOR THE SECOND CirCuIT 52 (1974). In 1984, 2,912 appeals were filed-a $7.8 \%$ increase over 1983 - of which 1,979 were civil cases. S. Flanders, ANNUAL REPORT of THE United StATes Courts for THE Second Circuit 3 (1984) [hereinafter cited as SeCOND Circurt REPORT]. Despite the increase, however, the Second Circuit has managed to avoid a backlog of pending cases by disposing of appeals quickly and efficiently. At the end of 1984, the Court's pending caseload per panel was the lowest in the nation. Id. at 2.

7. Twelve years ago, I wrote an article explaining the function of CAMP and analyzing statistics gathered since its inception. See Kaufman, The Pre-Argument Conference: An Appellate Procedural Reform, 74 Colum. L. Rev. 1094 (1974). Since then, many other studies have examined CAMP or other pre-hearing conference plans. See, e.g., A. PARTRIDGe \& A. Lind, A Reevaluation of THE Civil appeals Management Plan (1983) [hereinafter cited as A Reevaluation of CaMP]; Birnbaum \& Ellman, Pre-Argument Settlement Process in an Intermediate Appellate Court: The Second Department Experience, 43 BrookLYN L. Rev. 31 (1976) (discussing appellate settlement procedures in New York State appellate court); Goldman, The Civil Appeals Management Plan: An Experiment in Appellate Procedural Reform, 78 Colum. L. Rev. 1209 (1978) (concluding CAMP had not yet fulfilled expectations but recommending further study); Lay, A Blueprint for Judicial Management, 17 Creighron L. REv. 1047, 1062-67 (1983-84) (discussing Eighth Circuit appellate management plan); Marvell, Appellate Capacity and Caseload Growth, 16 Akron L. REv. 43, 77-84 (1982) (surveying pre-hearing settlement conferences and concluding that they "greatly increase settlements" and probably speed procedures, although evidence insufficient for definite conclusion); Rack, Pre-Argument Conferences in the Sixth Circuit Court of Appeals, 15 U. ToL. L. REv. 921 (1984).

8. The Second Circuit now has two full-time Staff Counsel.

9. An interesting by-product of CAMP was its use by the parties in ways never contemplated by its founders. In some large multi-defendant criminal cases, the parties asked for conferences to set dates for briefing and argument. They also capitalized upon this opportunity to avoid repetition in briefs and in the appendices, and to select a mutually acceptable lead counsel. This procedure is now conducted by a non-CAMP Staff Attorney in those multi-defendant actions that present intricate scheduling problems.

10. CAMP Rule 7. To ensure compliance with Staff Counsel scheduling orders, which impose shorter deadlines than those provided for by Federal Rule of Appellate Procedure 31(a), the sanction against appellants for noncompliance is dismissal of the appeal. In 1984, 186 appeals were dismissed for failure to comply with the scheduling order. SECOND CIRCUIT REPORT, supra note 5, at 8. Sanctions against appellees may include taxation of costs or, more rarely, denial of oral argument. CAMP Rule 7. 
filing of the record and briefs. ${ }^{11}$ Staff Counsel is also authorized to dispose of motions dealing with the filing of oversize briefs.

Staff Counsel, attorneys for the parties, and on occasion the parties themselves participate in the conferences, which may last from one hour to several hours. When necessary, more than one conference is held. If the parties fail to resolve the dispute at conference, however, they retain the right to proceed to briefing and oral argument.

For Staff Counsel, the most gratifying aspect of CAMP is the role he plays in encouraging settlement. As one Staff Counsel explained, CAMP can, at its best, serve a "healing function" for parties who have been further driven apart by the litigation process. ${ }^{12}$ At the pre-argument conference, Staff Counsel invites the parties to state their views of the facts and legal issues of the case and to discuss the lower court opinion. While strictly abiding by the policy against coercing settlement, ${ }^{13}$ Staff Counsel does not hesitate to point out weaknesses in an attorney's argument, or to recommend withdrawal of frivolous or hopeless appeals.

The Court vests considerable authority in Staff Counsel, so counsel for the parties are expected to approach these conferences seriously and to make a good-faith effort to resolve disputes before argument when possible. The pre-argument conference guidelines advise counsel to be "thoroughly prepared to discuss in depth the alleged errors and the reasons for their positions," and to "obtain advance authority from their clients to make such commitments as may reasonably be anticipated."14 On occasion, an attorney in an adversary proceeding will object to a suggestion by Staff Counsel that he believes infringes on the attorney-client relationship. ${ }^{16}$ On the other hand, the CAMP process has brought to light some

11. CAMP Rule 4. The underlying concept of CAMP is that parties are more likely to resolve their differences before argument if they have not already invested large amounts of time and money in the preparation of the appeal. The first conference is, therefore, scheduled well in advance of the deadline for the filing of briefs.

12. Interview with Frank Scardilli, Staff Counsel for CAMP, in New York City (Oct. 18, 1985).

13. See infra note 25 and accompanying text. In 1976, Eugene Goodman brought an action against his corporate employer, charging that its promotion plan discriminated against him on the basis of age. After Goodman won a substantial money judgment in the district court, his employer appealed to the Second Circuit. Goodman, his financial resources exhausted, defended his judgment pro se. In an extraordinary book recounting his experiences with the judicial system, Goodman describes his CAMP conference in terms that put to rest any suggestion that CAMP fosters pressured settlements. Despite his refusal to accept settlement on any terms, Goodman praises CAMP Staff Counsel Frank Scardilli as being "one of the few lawyers I was exposed to in the long proceedings who projected an extra dimension of thoughtful humanity. . . Mr. Scardilli spoke carefully, focusing on my own interests. I shall always be grateful for his civility and his concern." E. Goodman, ALL THE JUSTICE I COULD AFFord 231-32 (1983).

14. CAMP Guidelines, reprinted in Appeals to the Second Circurt, at 116 (5th ed. 1984).

15. Requests by staff counsel for permission to talk with clients form one of the few categories of complaints made by attorneys who have participated in CAMP. See A REEvaluation of CAMP, supra note 7, at 63-69. In 1982, the Second Circuit adopted guidelines for pre-argument conferences specifically authorizing Staff Counsel to request the presence of clients at conference but prohibiting 
of the less savory elements of the legal profession-for example, the attorney for an appellee who, when Staff Counsel recommended that the appellant withdraw the appeal, angrily objected, "You are cheating me out of a fee!"16

Early in CAMP's development, some believed that certain categories of appeals would be more amenable to settlement than others. Appeals involving money damages, for example, were considered more likely to settle than those regarding injunctive relief. ${ }^{17}$ Cases were therefore screened by Staff Counsel, and only those considered to be promising candidates for early disposition were scheduled for conference. ${ }^{18}$ Systematic screening was abandoned in 1977, and there is no evidence that the settlement rate varies among different kinds of cases. ${ }^{19}$ Today virtually all civil cases are sent to conference, including bankruptcy appeals and appeals in which the United States or an administrative agency is a party. ${ }^{20}$

In 1977, a second Staff Counsel was appointed to handle the additional cases occasioned by the reduced screening process. Despite the heavier caseload assumed by CAMP, the average time between the docketing of the appeal and the conference increased only ever so slightly, from $19.5^{21}$ to 20 days. $^{22}$ Although Staff Counsel still urges attorneys to attend conferences in person, a requirement in CAMP's early days, the guidelines now permit Staff Counsel to hold conferences by telephone or at locations other than New York City in appropriate cases.

Participation in the CAMP conference is required of counsel, but the ultimate decision to settle, withdraw, or proceed to briefing and argument remains, of course, with the parties. ${ }^{23}$ Participation by judges in pre-

direct contact with parties outside of the presence of their attorneys. See CAMP Guidelines, supra note 14.

16. Interview with Frank Scardilli, Staff Counsel for CAMP, in New York City (Oct. 18, 1985).

17. See Kaufman, supra note 7, at 1099-1100.

18. Cases were not chosen for conference based strictly on the type of relief sought, but rather were selected at the discretion of Staff Counsel. See Goldman, supra note 7, at 1213-14 (discretion left to staff counsel because "many factors" believed to influence likelihood of settlement).

19. A ReEvaluation of CAMP, supra note 7, at $42-43$ (statistics for four major classifications of civil appeals in first half of 1978-79 term indicate no difference in settlement rates induced by CAMP.

20. On a rare occasion, conference and settlement will occur even after oral argument. Such was the case in DeFelice v. Board of Educ., appeal docketed, No. 74-2221 (2d Cir. Sept. 6, 1974), an appeal involving complicated issues of integration and zoning. After years of litigation culminating in oral argument before the Second Circuit, the parties suggested another conference with CAMP Staff Counsel. Shortly thereafter, they reached a settlement.

21. Kaufman, supra note 7, at 1098 (statistics covering Apr. 15 to Sept. 1, 1974).

22. A Refval.untion of CAMP, supra note 7, at 16 (average time from docketing to conference in 1978-79 sample was 17 days for one staff counsel and 23 days for other).

23. The Second Circuit is the only federal court of appeals that preserves the right of every party to be heard in oral argument. The presiding judge determines the time permitted for oral argument in a given case.

The Second Circuit now disposes of meritless appeals where the law has been well established by summary orders entered after argument, a practice that displaced the court's former custom of render- 
argument conferences is a widely debated issue, primarily because the psychological effect of having a judge conduct a conference is difficult to evaluate. ${ }^{24}$ The Second Circuit has insisted on excluding judges from participating in CAMP procedures. By keeping judges out of the conferences, CAMP reduces the demand on judicial resources and prevents the need for a judge to disqualify himself from an appeal because he had been present at the conference. The absence of judges also promotes a greater degree of candor. By far the most important reason for withholding judicial participation in CAMP, however, is to avoid any perception that the court is attempting to pressure the parties to settle or withdraw the appeal. ${ }^{25}$ Staff Counsel may provide the parties with a candid and objective assessment of their arguments. On occasion, he will go so far as to predict the outcome of the appeal. Because ordinary words assume unintended significance when clothed in judicial garb-Staff Counsel do not wear robes or preside in a courtroom, and the proceedings have an air of informality-similar comments, if uttered by a judge, would likely be viewed more as threats than as advice.

To further promote candor in conferences, GAMP guidelines prohibit counsel for the parties, or anyone else, from informing members of the Court about discussions or actions at a conference. ${ }^{26} \mathrm{~A}$ party that breaches this confidence may be censured by the court. In a sui generis situation, In re Lake Utopia Paper Ltd. ${ }^{27}$ the appellee revealed in its brief that Staff Counsel viewed the appeal as baseless and had advised the appellant to withdraw the appeal. In its written opinion, the court "deplore[d] any compromising of confidentiality by counsel for a party to the appeal."28

ing a decision from the bench. See Kaufman, supra note 7, at 1094 n.4. Summary orders set forth, sometimes quite extensively, the reasons for the Court's decision. They do not, however, have any precedential value. 2D GrR. R. $\S 0.23$.

24. The Seventh Circuit has experimented by conducting conferences at which only a Staff Attorney was present, as well as conferences at which both a judge and a Staff Attorney were present. An analysis of the results did not reveal any difference in the rate of settlement. See J. Goldman, ThE Seventh Gircuit Preappeal Program: An Evaluation 43 (1982).

25. "Blackjacked settlements" pose a potential problem for any court-sponsored program offering alternative dispute resolution. Recently, the Second Circuit heard an appeal from a decision imposing sanctions on a party who settled for $\$ 20,000$ one day after trial had begun. At a pre-trial conference, the district judge had recommended settlement for a sum between $\$ 20,000$ and $\$ 30,000$ and warned that if the parties settled for a comparable sum after the trial began he would impose sanctions on the dilatory party. The Second Circuit reversed the sanctions, noting that "pressure tactics to coerce settlement simply are not permissible." Kothe v. Smith, 771 F.2d 667, 669 (2d Cir. 1985).

26. CAMP Guidelines, supra note 14 .

27. 608 F.2d 928 (2d Cir. 1979).

28. Id. at 930 . 


\section{Measures of Success}

Because issues in appeals differ widely, the disposition rates of appeals do not easily lend themselves to measurement or comparison. ${ }^{29}$ Recent statistics indicate, however, that CAMP reduces by one-sixth the number of cases argued before the Second Circuit, ${ }^{30}$ usually also eliminating costly briefs. Each settlement achieved by CAMP saves the time of not just one judge, as in the district court, but of at least three appellate judges. Moreover, in cases that proceed to oral argument, Staff Counsel disposes of many procedural motions that arise in a case between the time it is docketed and the day it is argued before judges. According to one estimate, CAMP assumes the workload of two circuit judges at approximately onethird the cost. ${ }^{31}$

Beyond dollar savings, CAMP is notable for its effectiveness in moving cases through the appellate court system. One study found that almost one-half of CAMP appeals were disposed of within ninety days of docketing, compared to only one-fifth-20.5\% - of the control group of cases not assigned to GAMP. ${ }^{32}$ The settlement program has enabled the Second Gircuit to remain, for the ninth consecutive year, the federal court with the shortest time in the nation for processing appeals ${ }^{33}$-even while affording oral argument to every party desiring it.

\section{An Idea Gatches On: Pre-Argument Programs in Other Gircuits and State Appellate Courts}

If imitation is any measure of achievement, CAMP has indeed earned high marks. Since the inception of CAMP in 1974, four circuits ${ }^{34}$ and

29. The problems encountered in evaluating the effectiveness of pre-hearing settlement conferences are discussed in Marvell, supra note 7, at 79-80. One theory suggests the availability of settlement conferences at court expense may actually encourage the filing of appeals. Id. at 82-83. In general, however, commentators agree that pre-hearing settlement conferences expedite the appellate process. See J. Goldman, supra note 24, at 42-43 (recommending continuation of Seventh Circuit conference program because of its effect in reducing number of motions and expediting hearings); $A$ ReEvaluation of CAMP, supra note 7, at 59 ("best single estimate" suggests CAMP saves 44 days in appeals process); Birnbaum \& Ellman, supra note 7, at 43 (1976) ("[T]he number of settlements and withdrawals of appeals overwhelmingly compensates for the expenditure of staff time devoted to administration of the program."); Lay, supra note 7, at 1062-65 (Eighth Circuit's Civil Appeals Mediation Plan is one element of comprehensive procedures expediting appeals).

30. A Reevaluation of CAMP, supra note 7, at 6 . In 1984, 54\% of all cases terminated by the Second Circuit were resolved without oral argument or submission of briefs. SECOND CIRCUIT REPORT, supra note 5 , at 8.

31. Second Circuit Research Advisory Committee, Evaluation of the Civil Appeals Management Plan 5 (1981).

32. A ReEvaluation of GAMP, supra note 7, at 51-52.

33. SECOND Circuit REPORT, supra note 5, at 5. In 1984, the median processing time for civil cases in the Second Circuit was 6.2 months, as compared to 11.1 months nationwide. Id.

34. In January 1981, Chief Judge George Edwards of the Sixth Circuit examined the performance of CAMP procedures. Concluding his court might benefit from a similar program, Judge Edwards instituted the Sixth Circuit Pre-Argument Conference Program. Its progress is discussed in 
more than a dozen states have implemented or experimented with preargument conference programs. Although programs vary widely in structure and procedure, all share a commitment to improving the quality of appellate jurisprudence by offering guidance to the litigants shortly after the notice of appeal has been filed.

Some of the variations in other circuit court pre-argument programs reflect physical or structural differences among the circuits. ${ }^{35}$ More often, however, modifications in the pre-argument plans reflect each circuit's philosophy on the extent to which the court should become involved in a case before consideration on appeal. The Ninth Circuit Innovations Project, for example, schedules pre-briefing conferences principally for the purpose of clarifying issues on appeal, not to encourage settlement. ${ }^{36}$ If settlement is discussed, it is usually at the initiative of counsel for the parties, and the case is then referred to a magistrate or senior judge for further settlement discussions. ${ }^{37}$ Similarly, in the Seventh Circuit, which did not consider informal dispute resolution a viable goal of prehearing conferences, the main objectives were expediting scheduling and reducing the number and length of papers submitted. ${ }^{38}$

Rack, supra note 7.

The Seventh Gircuit Pre-Appeal Program, instituted in 1978, was intended as an experiment whose renewal would depend on the results of a careful evaluation. See J. Goldman, supra note 24, at 2. Despite a positive recommendation in 1982, see id. at 43 , the Seventh Circuit staff counsel discontinued pre-hearing conferences in 1983.

Following the lead of the Second Circuit, the Eighth Circuit implemented its Civil Appeals Mediation Plan. See Lay, supra note 7, at 1063-65. The Mediation Plan complements the Eighth Circuit's successful Appeals Expediter program, which oversees the timely filing of records and briefs. See L. Farmer, Appeals Expediting Systems: An Evaluation of Second and Eighth Circuit Procedures (1981).

Between 1982 and 1984, the Ninth Circuit, now the largest federal appellate court, implemented its Innovations Project. A comprehensive plan for improving case management, the Innovations Project includes a pre-briefing conference program. See J. Cecil, Administration OF JUSTICE IN A LaRGE Appellate Court: The Ninth Circuit Innovations Project 79-95 (1985).

35. The relatively small geographic area covered by the Second Circuit, for example, permits Staff Counsel to schedule a large number of conferences which attorneys can attend in person. In contrast, the Sixth Circuit conducts its conferences primarily by telephone because the attorneys are more evenly distributed throughout the circuit. Rack, supra note 7, at 923 n.7. For similar reasons, the Eighth Circuit holds conferences in a number of cities. Two-thirds of the Ninth Circuit conferences involve some telephone conferences, while others are held in San Francisco, Seattle, Portland, and Los Angeles. See J. Cecil, supra note 34, at 85.

The Sixth Circuit also chose to forego further implementation of a program for expediting appeals, reasoning that because the Circuit had a backlog of cases there was no need to shorten filing deadlines. Rack, supra note 7, at 923 n.7. Chief Judge Donald Lay of the Eighth Circuit, however, notes the Appeals Expediter program may give his Court incentive to manage its own work more efficiently. See Lay, supra note 7, at 1062-63.

36. J. CECIL, supra note 34, at 81-82.

37. Id. at 87. Pre-argument procedures might provide the seeds for other experimental plans. One pilot program in Washington provides for referral of the appeal to a member of the Federal Bar Association, who conducts the settlement discussions. Id. at 82 .

38. J. Goldman, supra note 24, at 2. Professor Goldman's study concluded that the Seventh Circuit program did expedite hearing dates and reduce the number of motions submitted to judges. The study, however, did not find any impact on brief length or settlement rates. Id. at 42-43. 


\section{Civil Appeals Management Plan}

The practice of submitting for conference only those appeals considered amenable to settlement has been abandoned by some circuits but retained by others. The Eighth Circuit, for example, confines its settlement program almost exclusively to appeals involving money judgments. ${ }^{30}$ As we have indicated, the Second Circuit abolished its own systematic screening in 1977, and a later study indicated no difference in rates of settlement for different kinds of cases. ${ }^{40}$ It is my view that reduction of the screening process has engendered a more even-handed administration of justice, extinguishing any notion that the court "hand picks" cases for settlement.

Appellate conference programs have not been limited to federal courts; state court interest in pre-hearing settlement conferences has been widespread. At least thirteen states now provide some form of pre-argument conference in their appellate court system. ${ }^{41}$ The enthusiastic reception accorded appellate alternative dispute resolution may reflect a special need of state courts to conserve judicial resources and raises the possibility that appeals commonly presented in state court may be particularly inclined toward settlement. ${ }^{42}$

\section{CoNCLUSION}

Is CAMP merely an administrative procedure that robs parties of their right to appeal? For a multitude of reasons, the answer is no. First, we must ask ourselves whether the rising number of appeals includes a large number of cases undeserving of appellate review; I believe it does. Docket growth will probably continue so long as federal circuit courts lack the discretionary jurisdiction over appeals enjoyed by the United States Supreme Court, increasing the demands made on the time of appellate judges. ${ }^{43}$ Yet those of us who favor innovation in judicial administration are wary of promoting efficient case management at the expense of compromising a party's right to appeal. CAMP reduces frivolous appeals while preserving the availability of appellate review. Staff Counsel often identifies weaknesses in the arguments of parties who bring meritless

39. The Eighth Circuit excludes from conferences all Social Security cases, dismissals for a lack of jurisdiction, interlocutory appeals, requests for injunctions, government agency cases, federal income tax disputes, Title VII and $\S 1983$ appeals, labor arbitrations, and ERISA suits. Lay, supra note 7, at 1063.

40. See supra note 19. But see J. Cecil, supra note 34, at 94 (finding little benefit, Ninth Circuit no longer schedules social security and immigration appeals for conference).

41. National. Center for State Courts, State Appellate Caseload Growth (1985) (documentary appendix).

42. In New Jersey, where the Supreme Court has offered a Civil Appeals Settlement Program since 1981 , more than $40 \%$ of appeals concerning matrimonial affairs, contracts, non-automobile torts, and real property were settled. Seidman, Our New Appellate Settlement Program, N.J. LAw., Winter 1984 , at 22.

43. For discussion of the effects of docket growth on adjudication, see R. POSNER, supra note 3 , at 94-129, 318. 
claims, and in such cases, the appellant not infrequently decides to withdraw the appeal.

Even in non-frivolous cases, however, as judges we must consider whether parties, if given the opportunity, might not arrive at a mutually agreeable solution without full and final appellate adjudication. Before CAMP, we knew that settlement was a frequent by-product of pre-trial conferences in the district court; what we did not know was whether conferences would also produce settlements on the appellate level where one party has already prevailed in the court below. GAMP has demonstrated that parties welcome settlements in appealed cases, and the reason is often purely pragmatic. The party that prevailed below realizes that the cost and risk of defending the appeal will exceed the benefits obtained in the lower court judgment. Some may argue that a "correct" legal decision is more important than the financial savings to the litigants, but part of the court's responsibility is to bring this choice to the parties' attention.

Parties may also abandon an appeal to avoid the difficulties and unpleasantries of protracted litigation. In my experience, appeals are especially likely to be dropped when the litigation involves family members or former business partners. These cases call to mind my long-time friend and colleague Judge Harold Medina, who viewed with satisfaction his experience as a district judge in negotiating settlement agreements. Judge Medina once described his role in a particularly acrimonious dispute among embittered members of a family. He was proud of having made peace without a judgment in that case despite his vow "never, never" to pursue what he considered "blackjacked settlements."

Like Judge Medina, I have long suspected the best justice is done when the parties voluntarily abandon litigation in favor of a solution that does not leave one party scarred and the other exalted. This is not merely a casual observation. Rather, it is a humble acknowledgement that the world is not black and white, but is colored by emotions and experiences that are the very soul of the law. ${ }^{45}$ In CAMP I foresaw the possibility, and now have observed the reality, of recovering some of the humanity the judicial system has lost in trying to keep pace with the nation's explosion of litigation.

Regrettably, the tradition and propriety of the judicial office has prompted some to view the pursuit of compromise as incongruous with the judge's role. CAMP's most readily apparent contribution may be the ex-

44. Howard, Judge Harold R. Medina: The 'Freshman' Years, 69 JudicatuRE, 126, 134 (1985).

45. During a different kind of dispute many years ago, Edmund Burke observed: "All government, indeed every human benefit and enjoyment, every virtue, and every prudent act, is founded on compromise and barter." E. BURKE, SPEECH ON CoNCILIATION wITH AMERIGA 62 (H. Lamont ed. 1897). 
Civil Appeals Management Plan

pedition of case processing, but the success of CAMP in its first decade also has a more profound meaning - that settlement and compromise are neither beyond the reach, nor beneath the dignity, of our appellate courts. 


$$
\text { , }
$$

